\title{
ОРГАНІЗАЦІЙНО-ПРАВОВІ ПИТАННЯ ФІКСУВАННЯ ОБШУКУ ТЕХНІЧНИМИ ЗАСОБАМИ
}

Смірнов О. С., Тетерятник Г. К.

\begin{abstract}
Стаття присвячена питанням фіксування технічними засобами ходу та результатів проведення слідчої (розшукової) дії - обшуку. У роботі звертається увага на недосконалість кримінального процесуального законодавства в частині регламентації питань фіксування обшуку технічними засобами. Вказується на відсутність єдності термінології, яка застосовується законодавцем у нормах, які регламентують зазначене питання, розрізнену правозастосовну практику. Автором досліджуються організаційно-правові питання повноти та безперервності проведення аудіо- $і$ відеозапису обшуку, значення дотримання умов проведення фіксування обшуку під час вирішення питання nро допустимість доказів. Надаються пропозиції із вдосконалення кримінального процесуального законодавства в частині фіксування обшуку технічними засобами.

Ключові слова: обшук, слідча (розшукова) дія, технічні засоби, фіксування, аудіо- $і$ відеозапис.
\end{abstract}

Статья посвячена вопросам фиксации хода и результатов проведения следственного (розыскного) действия обыска. В работе обращается внимание на несовершенство уголовного процессуального законодательства в части регламентации вопросов фиксации обыска техническими средствами. Указывается на отсутствие единства терминологии, которая используется законодателем в нормах, регламентирующих данный вопрос, разобщенную правоприменительную практику. Автором исследуются организационно-правовые вопросы полноты и непрерывности аудио- и видеофиксации обыска, значение соблюдения условий проведения фиксации обыска при решении вопроса о допустимости доказательств. В работе представлены предложения автора по усовершенствованию уголовного процессуального законодательства в части фиксации обыска техническими средствами.

Ключевые слова: обыск, следственное (розыскное) действие, технические средства, фиксация, аудио- и видеозапись.

The article is devoted to fixing the course and results of the investigative (search) action - the search. Mandatory fixation of the search was provided for by the laws of Ukraine, which amended the Code of Criminal Procedure, in 2017. At the same time, the norms of the Code of Criminal Procedure of Ukraine still contain a number of inaccuracies and contradictions regarding the fixation of the search by technical means. These problems affect the effectiveness of the search, the possibility of using its results in evidence. The article provides an analysis of the norms of the Code of Criminal Procedure of Ukraine governing the conduct of audio and video recording of a search. The author has investigated the scientific sources related to this problem, formulated his own vision of resolving discussion issues in the aspect of the chosen problems.

The paper draws attention to the imperfection of the criminal procedural legislation regarding regulation of issues of fixing the search by technical means. It points out the lack of unity

Смірнов О. С., Тетерятник Г. К., 2019 of terminology that the legislator uses in the rules governing this issue, a fragmented law enforcement practice.

The author examines the organizational and legal issues of the completeness and continuity of the audio-video recording of the search, the importance of observing the conditions for recording the search when deciding on the admissibility of evidence. The issue of the mandatory fixation of various types of searches by technical means is analyzed. The paper presents the author's suggestions for improving the criminal procedural law in terms of fixing the search by technical means. The author comes to the conclusion that not all types of searches are necessarily subject to audio-video fixations. The technical fixation of the search, which is carried out without the determination of an investigating judge, is not mandatory, since this procedural action is among the urgent ones.

It is proposed to develop instructions for bodies and units authorized to conduct a search, which would regulate the features of using technical means of fixation and audio-video recording during this investigative (search) action.

Key words: search, investigative (search) action, technical means, fixation, audio-video recording.

Постановка проблеми. Обшук $є$ однією з найбільш правообмежуючих слідчих (розшукових) дій. 3 приводу процесуального порядку його проведення виникає досить багато спірних питань та процесуальних конфліктів. Попри організаційно-тактичну складність, велику кількість скарг на дії сторони обвинувачення після проведення обшуку, неоднозначне вирішення судом питань щодо допустимості доказів, отриманих під час проведення обшуків, ця слідча (розшукова) дія $\epsilon$ досить поширеною.

Як показує судова статистика, кількість клопотань щодо проведення обшуку щорічно збільшується: станом на 01.05.2014 до слідчих суддів місцевих загальних судів надійшло 86658 клопотань про надання дозволу на обшук житла чи іншого володіння особи, з яких 71678 (82,7\%) задоволено, у задоволенні 13645 (15,7\%) клопотань - відмовлено; у 2015 році на розгляд місцевих судів надійшло 75162 клопотання про проведення обшуку житла чи іншого володіння особи (із них задоволено - $61186(81,4 \%)$ ), у 2016 р. - 94746 (із них задоволено - $76922(81,2 \%)$ ), у 2017 р. - 118884 (із них задоволено - 96331 (81\%)) [1; 2].

Стан дослідження. Процесуальні та криміналістичні питання проведення обшуку на сучасному етапі досліджувалися багатьма вченими та практикуючими адвокатами: І. Гловюк, Д. Зеленюком, М. Комаровою, Т. Пошиванюком, О. Стареньким, О. Татаровим, Р. Шехавцовим та багатьма іншими.

Не оминув своєю увагою вирішення цієї проблематики і законодавець, який неодноразово з моменту набрання чинності КПК України 2012 року вносив зміни до норм, що регулюють питання, пов'язані із проведенням обшуку та використанням його результатів у дока- 
зуванні. Останні такі зміни відбулися у зв'язку з прийняттям Закону України «Про внесення змін до деяких законодавчих актів щодо забезпечення дотримання прав учасників кримінального провадження та інших осіб правоохоронними органами під час здійснення досудового розслідування» від 16 листопада 2017 року № 2213-VIII та Закону України «Про внесення змін до Господарського процесуального кодексу України, Цивільного процесуального кодексу України, Кодексу адміністративного судочинства України та інших законодавчих актів» від 03 жовтня 2017 року № 2147-VIII [3; 4].

Натомість, попри розвиток наукової думки та законодавства у напрямі нормативного врегулювання питань забезпечення прав учасників кримінального провадження під час проведення обшуку, використання його результатів у доказуванні, залишаються не досить врегульованими окремі питання його проведення та фіксування.

Метою статті $\epsilon$ отримання наукового результату у вигляді теоретично обґрунтованих положень щодо окремих питань фіксування обшуку технічними засобами та вдосконалення на їх основі чинного кримінального процесуального законодавства.

Виклад основних положень. Фіксування обшуку $\epsilon$ важливою гарантією законності його проведення та допустимості отриманих під час слідчої (розшукової) дії доказів. Водночас $€$ низка питань нормативного та організаційного характеру в частині забезпечення вимог КПК України щодо фіксування обшуку.

Загальні вимоги до фіксування обшуку як одного 3 видів слідчих (розшукових) дій сформульовані у главі 5 КПК України. Так, у ч. 2 ст. 104 КПК України зазначається: «Запис, здійснений за допомогою звукота відеозаписувальних технічних засобів під час проведення слідчим, прокурором обшуку, є невід'ємним додатком до протоколу. Дії та обставини проведення обшуку, не зафіксовані у записі, не можуть бути внесені до протоколу обшуку та використані як доказ у кримінальному провадженні».

Вимога щодо обов'язкового фіксування за допомогою аудіо- та відеозапису обшуку житла чи іншого володіння особи на підставі ухвали слідчого судді міститься у ч. 10 ст. 234 КПК України.

Крім того, у ч. 1 ст. 107 КПК України також зазначається, що виконання ухвали слідчого судді, суду про проведення обшуку в обов'язковому порядку фіксується за допомогою звуко- та відеозаписувальних технічних засобів.

На нашу думку, привертає увагу одразу декілька невідповідностей, які містяться у зазначених нормах. По-перше, це назва технічних засобів фіксації обшуку. У ч. 2 ст. 104, ч. 1 ст. 107 КПК України такі засоби визначені, як «звуко- та відеозаписувальні технічні засоби», а у ч. 10 ст. 234 КПК України йдеться про «аудіо- та відеозапис». О. Старенький, досліджуючи зазначене питання, справедливо звертає увагу на те, що засоби фіксації $є$ додатками до протоколу процесуальних дій, а ст. 105 КПК України серед переліку таких додатків містить «аудіо- та відеозапис процесуальної дії», а не «звуко- та відеозаписувальні технічні засоби» [5, с. 194]. Таким чином, необхідним $є$ узгодження термінології у зазначених статтях.

По-друге, іще одна певна суперечність між наведеними нормами існує щодо визначення видів обшуку, які підлягають обов'язковій фіксації за допомогою техніч- них засобів. Так, у ч. 2 ст. 104 КПК України вказується про обшук взагалі. У ч. 2 ст. 107 та ч. 10 ст. 234 КПК України - про обшук, який проводиться за ухвалою слідчого судді.

Таким чином, обшук, який у невідкладних випадках проводиться на підставі ст. 233 КПК України, до випадків обов'язкового фіксування технічними засобами не належить. Логічно, що такий підхід зумовлений виключністю підстав проведення обшуку без ухвали слідчого судді шляхом проникнення до житла чи іншого володіння особи. Водночас гарантією забезпечення прав учасників такого обшуку, допустимість та достовірність доказів, отриманих під час його проведення, доцільно забезпечувати застосуванням звуко- та відеозаписувальних технічних засобів і в цьому разі. О. Старенький пропонує нормативно закріпити обов'язковий аудіота відеозапис і для зазначеного виду обшуку [5, с. 194]. На нашу думку, виключність підстав проведення обшуку без ухвали слідчого судді у невідкладних випадах, пов'язаних із врятуванням життя людей та майна чи з безпосереднім переслідуванням осіб, які підозрюються у скоєнні злочину, вказує на те, що особи, які у таких випадках проводять обшук, мусять діяти оперативно, терміново. А тому не завжди $є$ можливість здійснення технічного запису такого обшуку. Вважаємо, що необхідність аудіо- та відеозапису обшуку без ухвали слідчого судді носить рекомендаційний характер.

Крім того, як справедливо зауважують учені, учасникам обшуку нічого не заважає заявити клопотання про проведення технічної фіксації обшуку за допомогою аудіо- та відеозапису в порядку ч. 1 ст. 107 КПК України, адже у цьому разі слідчий, прокурор уже будуть зобов'язані здійснювати таку фіксацію [6].

По-третє, слід звернути увагу, що процитовані норми хоча й не містять вимоги щодо безперервної відеозйомки обшуку, але ч. 2 ст. 104 КПК України вказує на необхідність саме такої фіксації, адже формулювання про те, що «Дії та обставини проведення обшуку, не зафіксовані у записі, не можуть бути внесені до протоколу обшуку та використані як доказ у кримінальному провадженні». Розмірковуючи над зазначеним питанням, окремі процесуалісти звертаються до ч. 5 ст. 27 КПК України, у якій зазначається, що під час судового розгляду та у випадках, передбачених КПК, під час досудового розслідування забезпечується повне фіксування судового засідання та процесуальних дій за допомогою звуко- та відеозаписувальних технічних засобів. На підставі співставлення цих норм М. Комарова робить висновок, що «повне фіксування», як видається, свідчить про необхідність саме безперервного, суцільного фіксування процесуальних дій, зокрема обшуку, на що слід звертати увагу під час надання правової допомоги у кримінальному провадженні [7, с. 81]. Адвокат Д. Зеленюк, навпаки, звертає увагу на те, що «стаття 27 КПК України, яка закріплює вимогу щодо «повного» фіксування процесуальної дії, не розкриває змісту цього поняття та прямо не передбачає заборону переривати таке фіксування» [8].

На нашу думку, така слідча (розшукова) дія, як обшук, не може фіксуватися частково. 3 урахуванням положень ч. 2 ст. 104 КПК України, згідно з якими дії та обставини проведення обшуку, не зафіксовані у записі, не можуть бути внесені до протоколу обшуку та використані як доказ у кримінальному провадженні, 
відсутність безперервного запису може створити підстави для оскарження законності отриманих під час обшуку відомостей. Адже навіть відсутність відеозапису протягом певного часу може стати підставою для осіб, інтереси яких обмежувалися під час проведення обшуку, щоби оскаржувати законність дій сторони обвинувачення, які не фіксувалися. Крім того, у протоколі слідчої (розшукової) дії має фіксуватися ії хід та результати. Виникнення будь-яких непередбачуваних під час обшуку ситуацій, які б мали бути зафіксовані у протоколі обшуку, унеможливлено внаслідок заборони вносити такі відомості до протоколу.

Водночас виникає питання щодо характеристик технічних засобів, які мають використовуватися під час проведення обшуку. На практиці обшуки можуть тривати від декількох годин і більше доби. Таким чином, в арсеналі осіб, які проводять обшук, мають бути такі технічні засоби, які можуть працювати безперервно досить тривалий час. Логічно, що необхідною умовою ефективності такого засобу аудіо- і відеозапису $є$ його якісні технічні характеристики, які мають забезпечувати чіткість звуку та зображення.

Проблемним аспектом $€$ також визначення моменту початку та закінчення відеозапису проведення обшуку, законодавство не містить вимог щодо необхідності присутності понятих у кадрі, запису вилучення тощо.

Серед процесуалістів $\epsilon$ різні думки щодо вирішення цього питання. Д. Зеленюк, звертаючи увагу на негативну практику органів досудового розслідування запрошувати на обшук понятих, які не відповідають вимозі щодо «незаінтересованих осіб» відповідно до ст. 223 КПК України, вважає доцільним у протокол обшуку включати процес їх добору, що і слугуватиме початковим моментом відеофіксації [8]. Інші вчені стверджують, що відеозапис слід починати з того моменту, коли особі, яка $\epsilon$ власником приміщення, де проводиться обшук, слідчий пред'являє ухвалу про проведення обшуку, представляє учасників групи, називає ïx, у тому числі спеціаліста, i повідомляє про здійснення відеозапису окремих моментів обшуку [9, с. 40]. На практиці за загальним правилом проведення відеофіксації обшуку і розпочинається з моменту, коли слідчий вживає заходів для вручення ухвали особі, у якої проводиться обшук. На нашу думку, відеофіксація має розпочинатися не просто з моменту вручення ухвали на відео мають бути зафіксовані й інші обставини, які передували обшуку: добровільність допуску правоохоронців для проведення слідчої (розшукової) дії, відсутність порушень з їхнього боку та щодо самих правоохоронців тощо.

Науковці надають такі рекомендації щодо відеозапису ходу проведення обшуку: фіксування на відеофонограму всіх учасників обшуку і всіх осіб, що перебувають у приміщенні, яке обшукується; зйомка інтер'єру кімнат, які належить обшукати; роз'яснення прав і обов'язків учасників слідчої (розшукової) дії; заходи слідчого щодо організації обшуку; розміщення всіх осіб, які перебувають у приміщенні, в одному приміщенні (кімнаті); розподіл обов'язків між тими, хто обшукує; початок їх роботи; момент, коли слідчий пропонує власнику приміщення добровільно показати місця, де приховані предмети, цінності, які становлять інтерес у кримінальному провадженні та видати ї; місце збе- рігання, процес вилучення об'єктів, зйомка яких здійснюється крупним планом для кращого їх сприйняття у подальшому відтворенні запису; пояснення особи, яка ї надала та ін. [9, с. 40].

У частині наших рекомендацій щодо фіксування ходу проведення обшуку після його початку вважаємо, що поняті та особа, яка проводить обшук, мусять бути у кадрі. Особливе значення це має під час виявлення та вилучення речей і документів. Водночас слід зазначити, що навіть чітке фіксування дій слідчого та понятих під час обшуку повною мірою не може убезпечити сторону обвинувачення від скарг на те, що інші члени групи, залученої для проведення обшуку, не порушували прав осіб під час проведення слідчої (розшукової) дії, що часто і трапляється на практиці.

Більш зрозумілим та логічним $є$ момент закінчення відеозапису. Більшість процесуалістів, з якими ми повністю згодні, логічно зводять його до ознайомлення власника житла чи іншої особи, учасників обшуку із протоколом обшуку, внесення ними зауважень, заяв та клопотань та підписання протоколу [8; 9, с. 45].

Висновки. Таким чином, слід констатувати, що хоча прийняття Закону України «Про внесення змін до деяких законодавчих актів щодо забезпечення дотримання прав учасників кримінального провадження та інших осіб правоохоронними органами під час здійснення досудового розслідування» від 16 листопада 2017 року № 2213-VIII і створило додаткові гарантії забезпечення прав осіб під час проведення обшуку, але низка питань аудіо- та відеозапису цієї слідчої (розшукової) дії залишилася невирішеною [4]. Насамперед необхідно привести у відповідність з метою однозначного тлумачення закону термінологію, яка використовується у ст.ст. 104, 107, 236 КПК України в частині фіксування технічними засобами.

Слід зауважити, що наказом Міністерства юстиції України від 30.03.2018 № 951/5 була затверджена Інструкція про порядок використання в органах досудового розслідування Державної кримінально-виконавчої служби України технічних засобів фіксування кримінального провадження під час проведення окремих процесуальних дій (натепер вона втратила чинність) [10]. В Інструкції досить детально визначалися загальні положення, основні терміни (поняття), порядок використання технічних засобів фіксування кримінального провадження під час проведення окремих слідчих (розшукових) дій, окремим підрозділом було визначено порядок фіксування обшуку за допомогою відеозапису, створення та зберігання оригінальних примірників та резервних копій.

На нашу думку, доцільними $€$ розробка та затвердження наказом подібної спільної інструкції органами та підрозділами, які уповноважені на проведення обшуків, яка б вирішувала на рівні підзаконного нормативно-правового акта окремі питання, пов'язані із застосуванням технічних засобів та проведенням аудіоі відеозапису обшуку.

Перспективним у контексті тематики видається 3'ясування питань, пов'язаних із використанням аудіоі відеозапису обшуку у доказуванні, компаративістське дослідження використання технічних засобів під час проведення обшуку за кримінальним процесуальним законодавством України та іноземних держав. 


\section{Література}

1. Судова влада України. Судова статистика. Звітність. URL: https: / /court.gov.ua/inshe/sudova_statystyka/ .

2. Узагальнення ВССУ судової практики щодо розгляду слідчим суддею клопотань про надання дозволу на проведення обшуку житла чи іншого володіння особи від 17 жовтня 2014 p. URL: http://sc.gov.ua/ua/uzagalnennja_ sudovoji_praktiki.html.

3. Про внесення змін до Господарського процесуального кодексу України, Цивільного процесуального кодексу України, Кодексу адміністративного судочинства України та інших законодавчих актів : Закон України від 3 жовт. 2017 p. № 2147-VII. URL: http://zakon3.rada.gov.ua/laws/ show/2147a-19.

4. Про внесення змін до деяких законодавчих актів щодо забезпечення дотримання прав учасників кримінального провадження та інших осіб правоохоронними органами під час здійснення досудового розслідування : Закон України від 16 лист. 2017 р. № 2214-VII. URL: https: / / zakon.rada.gov.ua/laws/show/2213-19

5. Старенький О.С. Обшук як засіб отримання доказів у кримінальному провадженні: окремі новели чинного Кримінального процесуального кодексу. Юридичний часопис Національної академії внутрішніх справ. 2018. № 1 (15). С. 190-204.

6. Відеофіксація під час винесення та виконання ухвали про обшук. URL: http://kdka.org.ua/2018/06/04/\%D0\%B2\% D1\%96\%D0\%B4\%D0\%B5\%D0\%BE\%D1\%84\%D1\%96\%D0\%BA\%D1\%81\% D0\%B0\%D1\%86\%D1\%96\%D1\%8F-\%D0\%BF\%D1\%96\%D0\%B4-\%D1\% 87\%D0\%B0\%D1\%81-\%D0\%B2\%D0\%B8\%D0\%BD\%D0\%B5\%D1\%81\%D0 \%B5\%D0\%BD\%D0\%BD\%D1\%8F-\%D1\%82\%D0\%B0-\%D0\%B2\%D0\%B8/.

\section{Організаційно-правові аспекти} досудового слідства

7. Комарова М.В. Правові та організаційні засади обшуку у кримінальному провадженні : дис. ... канд. юрид. наук : спец. 12.00.09. Київ, 2019. 256 с.

8. Зеленюк Д. Снимать нельзя останавливать: оглавных проблемах видеофиксации обыска. Вебресурс Pravo.ua. URL: https://pravo.ua/snimat-nelzja-ostanavlivat-o-glavnyhprobely-videofiksacii-obyska//.

9. Проведення слідчих (розшукових) дій із застосуванням звуко- та відеозаписувальних технічних засобів : методичні рекомендації / В.В. Невгад, Р.М. Дударець, А.А. Саковський, М.П. Климчук. Київ : Нац. акад. внутр. справ, 2018. 67 с.

10. Про затвердження Інструкції про порядок використання в органах досудового розслідування Державної кримінально-виконавчої служби України технічних засобів фіксування кримінального провадження під час проведення окремих процесуальних дій : Наказ Міністерства юстиції України від 30.03.2018 № 951/5. URL: https://zakon.rada.gov.ua/laws/main/z0390-18.

Смірнов О. С., аспірант Донецького юридичного інституту Міністерства внутрішніх справ України

Тетерятник Г. К., кандидат юридичних наук, завідувач кафедри кримінального процесу одеського державного університету внутрішніх справ 